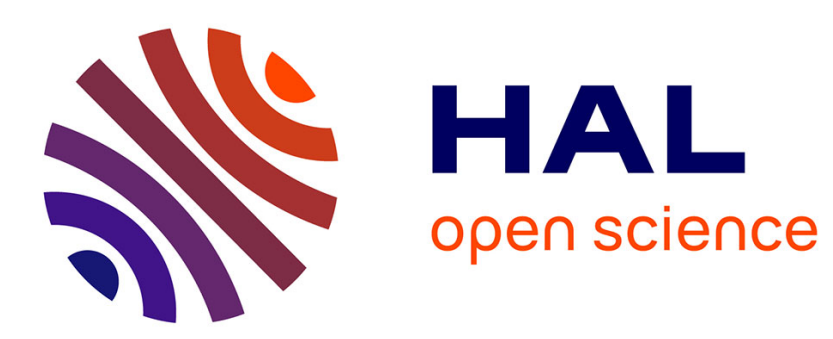

\title{
Life prediction of hot work tool steels subjected to thermomechanical fatigue
}

\author{
Alexis Oudin, Luc Penazzi, Farhad Rezai-Aria
}

\section{To cite this version:}

Alexis Oudin, Luc Penazzi, Farhad Rezai-Aria. Life prediction of hot work tool steels subjected to thermomechanical fatigue. Bulletin du cercle d'études des métaux, 2000, 17 (1), p.VII1-VII7. $10.1051 /$ mattech $/ 200088120067 \mathrm{~s}$. hal-01847831

\section{HAL Id: hal-01847831 \\ https://hal.science/hal-01847831}

Submitted on 6 Nov 2019

HAL is a multi-disciplinary open access archive for the deposit and dissemination of scientific research documents, whether they are published or not. The documents may come from teaching and research institutions in France or abroad, or from public or private research centers.
L'archive ouverte pluridisciplinaire HAL, est destinée au dépôt et à la diffusion de documents scientifiques de niveau recherche, publiés ou non, émanant des établissements d'enseignement et de recherche français ou étrangers, des laboratoires publics ou privés. 


\title{
LIFE PREDICTION OF HOT WORK TOOL STEELS SUBJECTED TO THERMOMECHANICAL FATIGUE
}

\author{
A. Oudin, L. Penazzi and F. Rézaï-Aria \\ Centre de Recherches Outillages, Matériaux et Procédés (CROMeP), \\ École des Mines d'Albi-Carmaux, France
}

\section{PRÉDICTION DE LA DURÉE DE VIE SOUS SOLLICITATIONS THERMOMÉCA- NIQUES DES OUTILLAGES EN ACIERS TRAVAILLANT À CHAUD}

RÉSUMÉ: La surface des outillages travaillant à chaud s'endommage par des interactions complexes de la sollicitation thermomécanique-usure-environnement réactif. Un essais de fatigue thermomécanique (FTM) utilisant des éprouvettes tubulaires a été mis au point. Les essais ont été menés sous cycles thermomécaniques hors-phases. La déformation mécanique est respectivement minimale $\left(\varepsilon_{m \text { min }}\right)$ lorsque la température est maximale $\left(T_{\max }\right)$ et est maximale $\left(\varepsilon_{m \max }\right)$ lorsque la température est minimale $T_{\text {min }}$. La vitesse de chauffage et de refroidissement est d'environ $4^{\circ} \mathrm{C} / \mathrm{s}$. Le comportement, l'endommagement et la durée de vie de deux aciers martensitiques revenus X38CrMoV5 (AISI HII) et 55NiCrMoV8 (47 HRC), sont étudiés. L'adoucissement cyclique est observé dans les deux aciers. Pour un niveau de l'amplitude de déformation donné $\left(\Delta \varepsilon_{m}=\varepsilon_{m \text { max }}-\varepsilon_{m \text { min }}\right)$, une très forte dépendance de la durée de vie à $T_{\text {mar }}$ est observée,

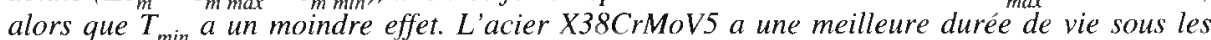
mêmes conditions de sollicitations. Les stries de fatigue observées sur les faciès de rupture de X38CrMov5 révèlent donc le caractère ductile de la propagation de fissure. Les faciès de rupture de l'acier 55NiCrMoV8 sont couverts d'une couche d'oxyde qui rend difficile la détection des stries de fatigue. La fissuration de la couche d'oxyde ainsi que l'écaillage sont observés sur la surface externe des éprouvettes. Un modèle phénoménologique uniaxial, de type puissance,

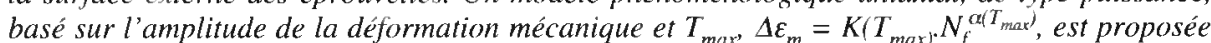
pour prédire la durée de vie sous des sollicitations aniothermes. La durée de vie en fatigue thermique ou thermomécanique de certains essais réalisés au laboratoire est prédite à un facteur 2 à 3. La capacité du modèle à prédire et identifier les régions critiques d'un outil de forge industriel est montré.

Mots CLÉS: Fatigue thermomécanique, fatigue thermique, aciers à outils, amorçage, propaga tion, fatigue à haute température.

ABSTRACT : Surface of hot work tools is damaged by complex thermomechanical-wear-reactive environment interactions. A thermomechanical fatigue (TMF) experiment using tubular specimens is developed. Tests are carried out under out-of-phase thermomechanical cycle. The mechanical strain is minimum $\left(\varepsilon_{\mathrm{m} \text { min }}\right)$ at upper temperature $\left(\mathrm{T}_{\max }\right)$ and it is maximum $\left(\varepsilon_{m \text { max }}\right)$ at lower temperature $\left(\mathrm{T}_{\min }\right)$ of thermal cycle. The behaviour, the damage and the fatigue life of two tempered martensitic steels X38CrMoV5 (AISI HI1) and 55NiCrMoV8 (47 HRC) are assessed. The effect of $T_{\min }$ and $T_{\max }$ is examined. Softening is observed for both steels. For a given mechanical strain amplitude $\left(\Delta \varepsilon_{\mathrm{m}}=\varepsilon_{\mathrm{m} \max }-\varepsilon_{\mathrm{m} \min }\right)$, a drastic dependence on $\mathrm{T}_{\max }$ is demonstrated, while $T_{\text {min }}$ has less important effect. $X 38 \mathrm{CrMoV} 5$ has a better TMF life. Ductile fatigue striations are observed on the fracture surface of $\mathrm{X} 38 \mathrm{CrMoV} 5$ specimens. The fracture surface of $55 \mathrm{NiCrMoV} 8$ specimens is covered by oxidation, making difficult to reveal the fatigue striations. Both oxide cracking and spalling are observed on the external surface of specimens. A phenomenological power law uniaxial model, based on the mechanical strain amplitude and $\mathrm{T}_{\max }, \Delta \boldsymbol{\varepsilon}_{\mathrm{m}}=\mathrm{K}\left(\mathrm{T}_{\max }\right) \cdot \mathrm{N}_{\mathrm{f}}^{\alpha\left(\mathrm{T}_{\max }\right)}$, is proposed to predict the life under non-isothermal fatigue sollicitations. The life of some thermal fatigue tests is predicted within a factor of two to three. The capability of the model to predict the critical regions of an industrial hot work tool is reported. KEY wORDS : Thermomechanical fatigue, thermal fatigue, tool steels, crack initiation, crack propagation, high temperature fatigue. outils 2000 - Interactions avec le produit mis en aeuvre et solutions " les 17 et 18 mai 2000 à Saint Étienne, lors des $39^{\circ}$ journées du Cercle d'Études des Métaux, qui l'a organisé en collaboration ave la section Sud-Est de la SF2M et l'Agence RhôneAlpes pour la maîtrise des matériaux. 
$\mathrm{T}$ he surface of the hot work tools is damaged under coupled thermomechanically and thermochemically sollicitations [1]. The loading and damage are complex combinations of non-isothermal fatigue $[1,2]$, wear [3] (in solidsolid contact, or erosion in solid-liquid contact) coupled with reactive environments, such as the oxidation or the corrosion (when a solid is in intimate contact with a liquid or a semiliquid). The well known heat checking (multiaxial cracking) [2, 4-6], is the basic feature of surface damage under TMF. The severity of the loading and the damage depends on the processing technique (forging, casting, die-casting or gravity casting, rolling, extrusion etc.) and also very much on the process parameters. Among the major parameters, are the initial and the upper temperatures of thermal cycle, the heating and the cooling rates, in particular if a cooling system with lubrication or surface protecting spray is employed. As tools are thermal systems [7], following an early transient situation, they work under a "quasi steady-state regime" with "stabilised" thermomechanical cycles.

The behaviour as well as the damage and life assessments under transient thermal conditions may be undertaken through isothermal fatigue [8] or non-isothermal fatigue experiments. In isothermal fatigue, the temperature is maintained constant through the whole experience and a conventional fatigue machine monitors cyclic straining. Two nonisothermal experiments are in general employed: thermal fatigue (TF, or thermal shock) $[2,4-6,9]$ and thermomechanical fatigue (TMF) $[10,11]$. In TF, a specimen (named "simple component" with respect to an industrial component) is submitted to fast transient temperature changes, which generate "internal" multiaxial mechanical strains and stresses. For the sake of the simplicity, consider an element of the surface is sollicitated under uniaxial loading. During thermal cycling, the free thermal expansion of the element $\left[\varepsilon_{t h}=\alpha . \Delta\left(T-T_{0}\right)\right]$, where $\alpha$ is the thermal expansion coefficient and $T_{0}$ is an initial temperature, e.g. $20^{\circ} \mathrm{C}$ ) is hindered by the bulk of the component. In fact, as a thermal gradient exists from the surface to the bulk, different points have different temperatures and present so different thermal expansions. This results in component self-constraining. The difference between the actual strain $\left(\varepsilon_{t o t a l}\right)$ and the free thermal expansion $\left(\varepsilon_{t h}\right)$ is called the mechanical strain $\left(\varepsilon_{m}=\varepsilon_{t o t a l}-\varepsilon_{t h}\right)$ which varies with time and temperature. The mechanical strain-temperature-time cycle is generally named "thermomechanical history" (TMF-history).

Mechanical strains and resulting thermal stresses are in general not directly accessible [9]. So the thermal and the mechanical parameters, i.e. "temperature/strain/stress/time" (TSSt) data, are mainly calculated by the appropriate thermomechanical analysis, employing for example the finite element method [2].

In TMF experiment, by "external" constraining of a fatigue specimen with a machine, for example, mechanical strains and stresses are generated and directly measured via relevant sensors (thermocouple, extensometer, and load cell). By a careful synchronisation of two independent "temperature-time" and "mechanical strain-time" cycles, a "mechanical strain-temperature-time" cycle can be imposed to the specimen. Depending upon the industrial applications, different TMF-history can be reproduced and assessed [11]. As an example, see TMF cycling which was performed to simulate TMF-history of the surface of a mould [12].
This contribution deals with an investigation on thermomechanical fatigue behaviour and damage of two tempered martensitic steels. A TMF experiment is developed using tubular specimens, induction heating and natural cooling. Effects of the lower and the upper temperatures of thermal cycle are investigated. A phenomenological uniaxial model is proposed to predict TMF life of hot work tool steels. The model is applied to predict the life of some thermal fatigue tests carried out at our laboratory and also to identify the critical zones of an industrial tool damaged by TMF cracking. These investigations have been carried-out with industrial support and so data are qualitatively presented hereafter in order to meet the confidentiality requirements.

\section{Experimental Procedures}

Both X38CrMoV5 (AISI H11) and 55NiCrMoV8 are currently investigated. Chemical compositions of both steels are given in Table I. Both steels have been annealed, quenched and heattreated to achieve the tempered martensitic microstructures with an initial hardness of $47 \mathrm{HRC}$. The effect of the initial hardness is currently under investigations [13].

Specimens are tubular with internal and external diameters of respectively $9 \mathrm{~mm}$ and $11 \mathrm{~mm}$, Figure 1 . Specimens are first pre-machined and then heat-treated to achieve the final microstructure as well as the desired hardness before to be remachined to the final dimensions. Both external and internal surfaces are polished parallel to the loading axis down to $R a=0.015 \mu \mathrm{m}$ roughness. Such specimens have previously been used to carry out TMF assessments on nickel base superalloys [11, 14].

Specimens are induction heated and naturally cooled with a temperature rate of about $4{ }^{\circ} \mathrm{C} / \mathrm{s}$. Tests are carried-out on a conventional push/pull hydraulic Schenck fatigue machine. First the modulus of elasticity is measured at different temperatures. Then few thermal cycles are performed for thermal stabilisation of all system (specimen, fixtures and extensometer rods, etc.). Mechanical strain at $T_{\min }$ is nil $\left(\varepsilon_{\max }=0\right)$ and it is minimum $\left(\varepsilon_{m \text { min }}\right)$ at $T_{\text {max }}$, Figure 2 . The strain ratio $\left(R_{\varepsilon}=\varepsilon_{m \text { min }} / \varepsilon_{\text {m max }}\right)$ is therefore $-\infty$. Following thermal stabilisation, Schenck simultaneously imposes two independent temperature-time and mechanical strain-time cycles to the specimen via the software Vistest.

Table I - Chemical composition of the two steels used (major elements, weight \%).

Tableau I - Composition chimique des aciers étudiés (éléments principaux, $\%$ en poids).

\begin{tabular}{|c|c|c|c|c|c|c|c|c|}
\hline Steel & Cr & C & Mn & V & Ni & Mo & Si & Fe \\
\hline X38CrMoV5 (Z38CDV5) & 5.05 & 0.40 & 0.49 & 0.47 & 0.2 & 1.25 & 0.92 & bal. \\
\hline 55NiCrMoV8 (55NCDV8) & 1.10 & 0.56 & 0.50 & 0.10 & 1.7 & 0.50 & 0.20 & \\
\hline
\end{tabular}

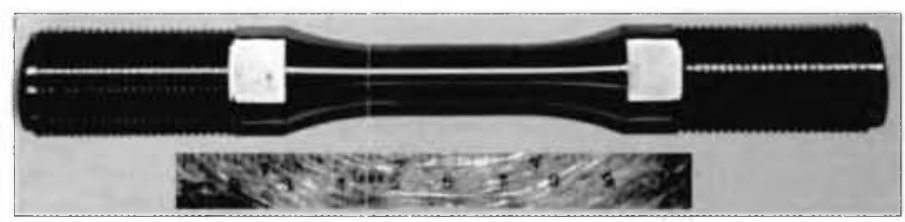

Fig. 1 - Thermomechanical tubular specimen.

Fig. I - Éprouvette tubulaire de fatigue thermomécanique. 


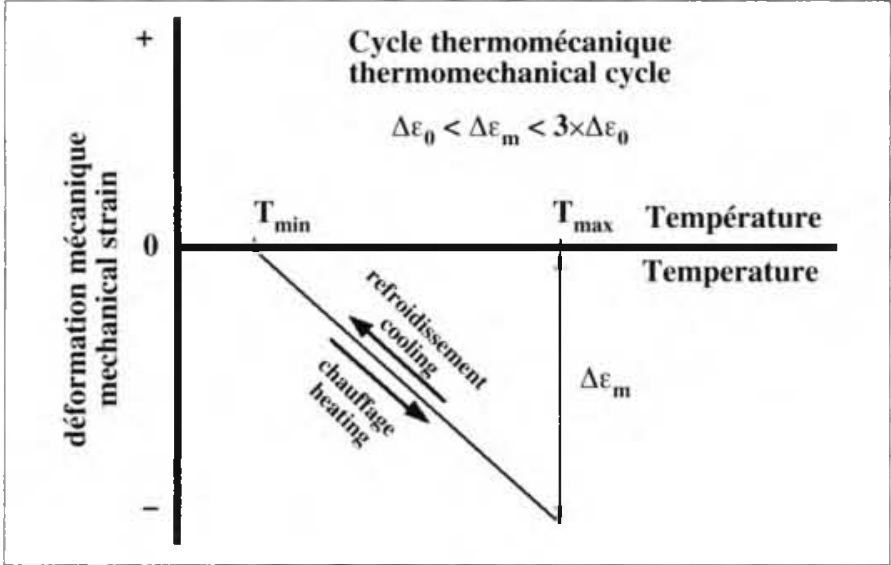

Fig. 2 - A typical out-of-phase TMF cycle showing the variation of the mechanical strain $\left(\varepsilon_{\mathrm{m}}\right)$ vs. temperature.

Fig. 2 - Un exemple de cycle de fatigue thermomécanique hors-phase montrant la variation de la déformation mécanique $\left(\varepsilon_{m}\right)$ en fonction de la température.

\section{Results and discussions}

Figure $3 \mathrm{a}$ and $\mathrm{b}$ present respectively the typical stress-mechanical strain $\left(\sigma-\varepsilon_{m}\right)$ and stress-inelastic strain $\left(\sigma-\varepsilon_{i n}\right)$ hysteresis loops at the first, the second and the half-life $(N / 2)$ TMF cycles. A large hysteresis loop is obtained in the first cycle. It demonstrates well what can occur in an element of the surface of an industrial tool, when begins the metal forming. Actually, during heating-up, the yield stress of the steels decreases and as the compressive mechanical strain enhances, the inelastic straining (sum of a time-independent plastic strain and a timedependent creep strain) can occur.

Under thermomechanical cycling however, the hysteresis loop enlarges continuously (compare loops at second and $N_{f} / 2$ cycles) and the inelastic strain amplitude $\left(\Delta \varepsilon_{\text {in }}\right.$ at $\left.\sigma=0\right)$ enhances. This enhancement is basically due to the plastically induced and the thermally induced softening of these steels which are very prone to the microstructure evolutions. This cyclic softening results in a continuous shifting of hysteresis loops to tensile stresses and in a development of tensile mean stresses $\left(\sigma_{\text {mean }}=\left(\sigma_{\text {max }}+o_{\text {min }}\right) / 2\right)$. Variation of the stress amplitude is very dependent upon mechanical strain amplitude, Figure 4. It seems that regardless the test conditions examined $\left(\Delta \varepsilon_{m}, T_{\max }\right.$ and $T_{\min }$ ), each steel reaches more or less rapidly an asymptotic tensile mean stress [13].

The effect of $T_{\min }$ and $T_{\max }$ was assessed. In one hand, $T_{\max }$ was maintained constant, while $T_{\min }$ was changed. In other tests, $T_{\min }$ was held constant and $T_{\max }$ was varied. As an example, the effect of $T_{\min }$ and $T_{\max }$ on the softening is reported in Figure $5 \mathrm{a}$ and $5 \mathrm{~b}$ as a function of $N / N_{f}$. As can be observed, $T_{\min }$ has a small effect on the stress amplitude relaxation (softening), while a drastic dependence on $T_{\max }$ is observed, Figure $5 \mathrm{~b}$. This more drastic dependence on $T_{\max }$ can be explained by the fact that at high temperatures, inelastic deformation processes and microstructure evolutions (dislocation motion, annihilation and rearrangement, carbide coarsening, etc.) are thermomechanically activated. It should be emphasised that $T_{\min }$, may influence the damage development under thermal fatigue loading. In fact, under TF sollicitations, amplitudes of strains or stresses are very much dependent on temperature range $\left(\Delta T=T_{\max }-T_{\min }\right)$, while in TMF, strains or stresses amplitudes and $\Delta T$ are independently imposed to the specimen.

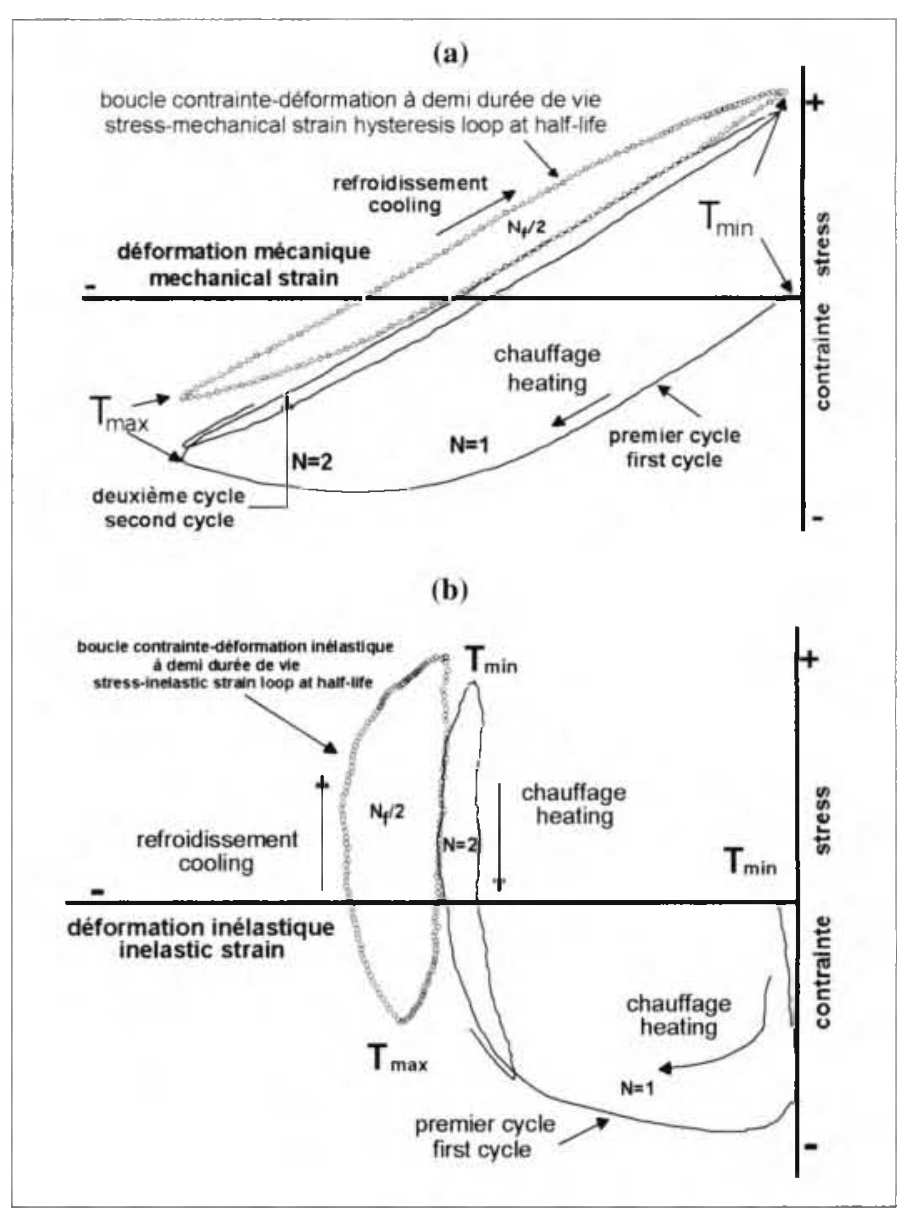

Fig. 3 - Stress-strain hysteresis loops a) mechanical strain, b) inelastic strain (X38CrMoV5).

Fig. 3 - Boucle d'hystérésis a) déformation mécanique, b) déformation inélastique (X38CrMoV5).

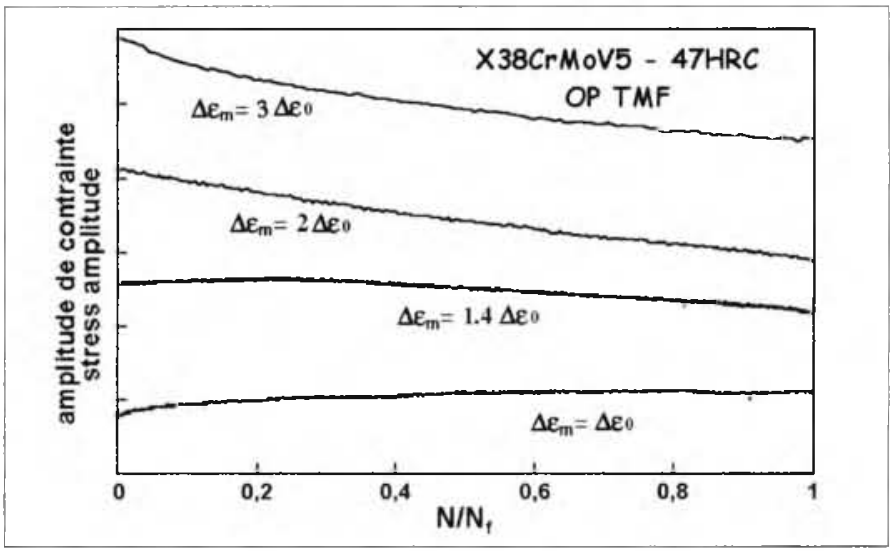

Fig. 4 - Effect of mechanical strain amplitude on the evolution of the stress amplitude vs. $\mathbf{N} / \mathrm{Nf}\left(\mathrm{T}_{\max }=\mathbf{T}_{\min }+450^{\circ} \mathrm{C}\right)$.

Fig. 4 - Effet de l'amplitude de la déformation mécanique sur l'évolution de l'amplitude de la contrainte en fonction de $N / N f\left(T_{\max }=T_{\min }+450^{\circ} \mathrm{C}\right)$.

The effect of $T_{\max }$ and $T_{\min }$ on the TMF life is reported as a function of mechanical strain amplitude $\left(\Delta \varepsilon=\varepsilon_{m \max }-\varepsilon_{m \text { min }}\right)$ in Figure 6. Other criteria (inelastic strain range, dissipated energy per cycle, etc.) are not reported here [13]. As can be observed, TMF life, $N_{f}$, is strongly $T_{\max }$ dependent. As an example, TMF life of both steels is compared in Figure 7. X38CrMoV5 presents a better TMF resistance. However, one can not claim at present whether the higher resistance of $\mathrm{X} 38 \mathrm{CrMoV} 5$ is due to higher crack propagation resistance or better crack initiation strength [13]. 
(a)

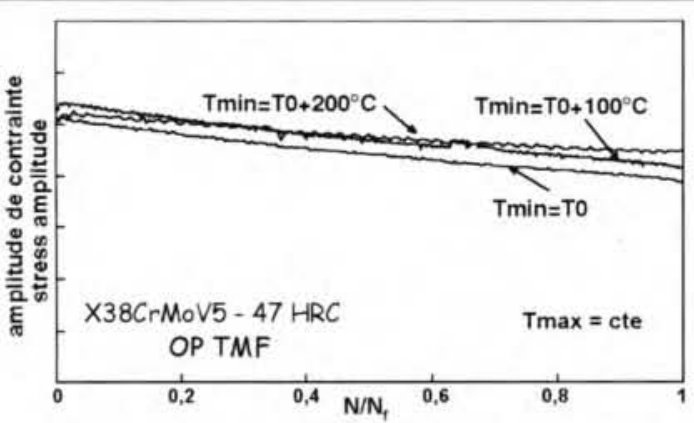

(b)

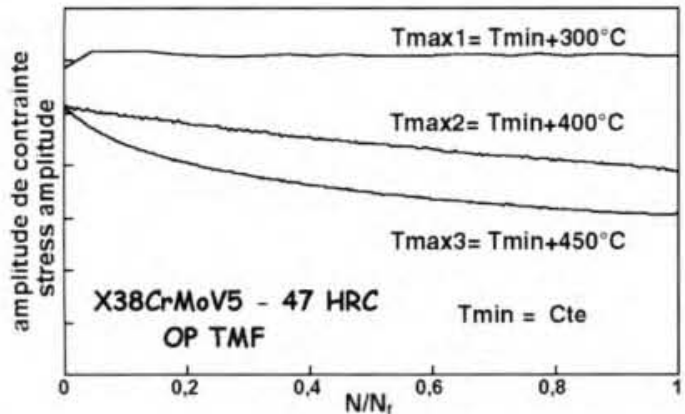

Fig. 5 - Effect of a) $T_{\min }$ and b) $T_{\max }$ on the evolution of the stress amplitude vs. $\mathbf{N} / \mathbf{N}_{\mathbf{f}}$

Fig. 5 - Effet de a) $T_{\min }$ et b) $T_{\max }$ sur l'évolution de l'amplitude de la contrainte en fonction de $N / N_{f}$

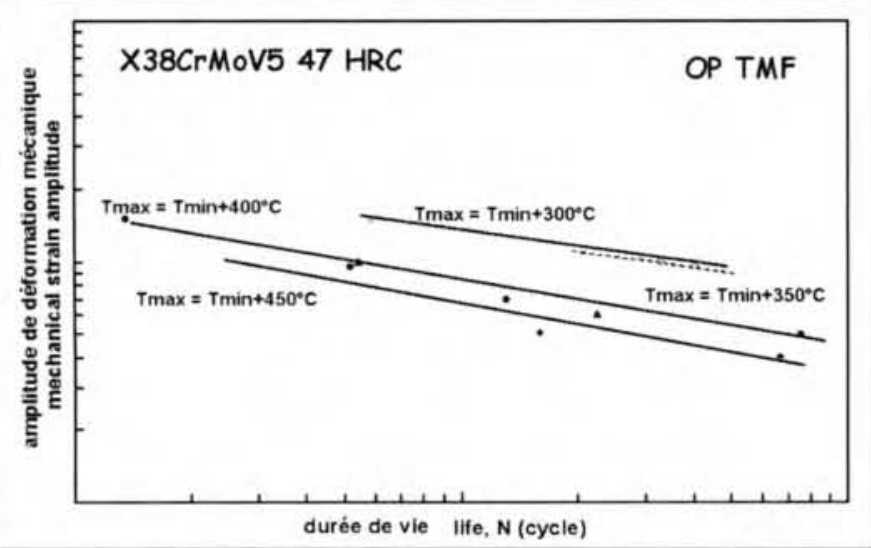

Fig. 6 - Thermomechanical fatigue life as a function of the mechanical strain amplitude.

Fig. 6-Durée de vie en fatigue thermomécanique en fonction de l'amplitude de la déformation mécanique.

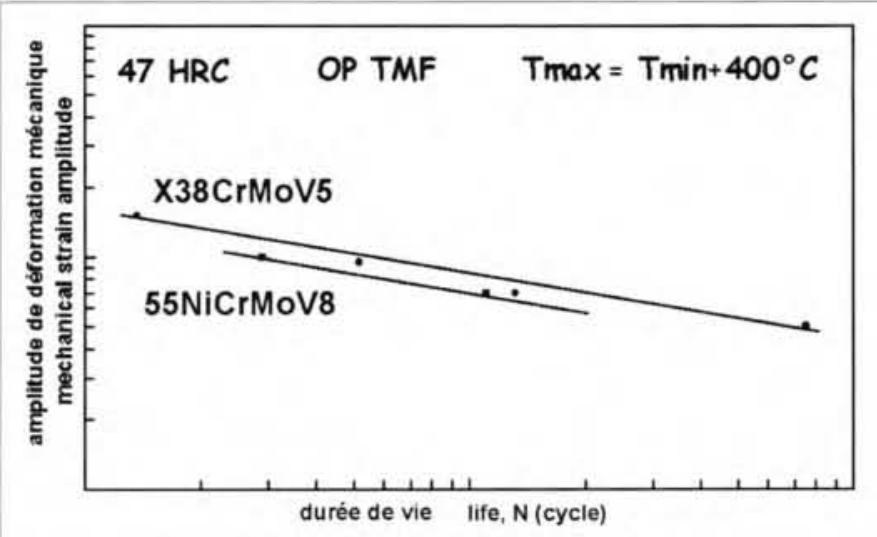

Fig. 7 - Comparison between TMF life of two tempered martensitic steels.

Fig. 7 - Comparaison de la durée de vie en fatigue thermomécanique de deux aciers martensitiques revenus.

\section{Damage mechanisms and crack propagation}

SEM observations of the external surface of specimens have revealed that even under macroscopic uniaxial testing, the surface is damaged by a microscopic complex and "multiaxial" loading. The oxide-scale cracking perpendicular or parallel and making a certain angle with respect to the main TMF loading axis are observed.

The oxide-scale cracking perpendicular to the TMF axis is the general feature and the principal cause of the crack initiation. The oxide scale spalling is, in addition observed. The spalling contribute to general degradation of steels by successive re-oxidation of the new freshly created surfaces. Gradually, the general oxidation transforms to a V-type oxidation, which develop towards the sub-surface and forms crack initiation sites. In-situ and continuous macroscopic observations on the external surface of some $\mathrm{X} 38 \mathrm{CrMoV} 5$ specimens have revealed the formation of slip bands. These bands may also contribute to the localisation of the oxidation and V-type crack initiation.

Observations on longitudinal section of X38CrMoV5 specimens have revealed that two oxide-scale layers are formed. One oxidescale layer is rich in $\mathrm{Cr}$ (in intimate contact with the base steel), and the other is a lower $\mathrm{Cr}$-content oxide-scale (in contact with air). $\mathrm{Cr}$-rich oxide-scale layer is not formed on $55 \mathrm{NiCrMoV} 8$ specimens as can be expected from its lower $\mathrm{Cr}$-content. The surface and the sub-surface of TMF specimens or tools can be regarded as a multilayer composite, consisting of one or two oxide-scale layers, and one layer of the substrate which losses continuously its mechanical properties and strength

SEM investigations reveal a ductile crack propagation aspect in $\mathrm{X} 38 \mathrm{CrMoV} 5$, since the fatigue striations are observed on the fracture surface of TMF specimens. The fracture surface of $55 \mathrm{NiCrMoV} 8$ specimens is covered by an oxide-layer, making difficult to reveal the fatigue striations. Currently, investigations are under progress to estimate the crack propagation rate as a function of the crack depth, by the well-known method consisting of accounting the mean fatigue striation distance per cycle [13].

\section{Life prediction model}

Based on TMF life results and taking into account that the actual commercial forming simulation softwares, like Forge $2^{\mathrm{TM}}$, consider basically the tools as thermoelastic or thermoelastoplastic, a phenomenological power law predictive life model based on $\Delta \varepsilon_{\mathrm{m}}$ and $T_{m a x}$ was proposed :

$$
\Delta \varepsilon_{m}=K\left(T_{\max }\right) \cdot N_{f}^{a\left(T_{\max }\right)}
$$

Both constants of this uniaxial law, i.e. $K\left(T_{\max }\right)$ and $\alpha\left(T_{\max }\right)$, are temperature dependant. As it was observed that TMF life is very much $T_{\max }$ dependant, it was assumed sufficient to express the variation of these constants with $T_{\max }$ by parabolic equations. In addition, transient regimes which occur during early "heating-up" of tools are not taken into the consideration.

The model was used to predict, in one hand the thermal fatigue life of some of specimens tested in our laboratory [15], and on the other hand, to predict the critical regions of an industrial tool in terms of the number of TMF cycles to initiate a macrocrack of about $0.5 \mathrm{~mm}$ depth.

As TF specimens and the industrial tool were first appropriately meshed for 2D-thermomechanical analyses. Then, TSSts 


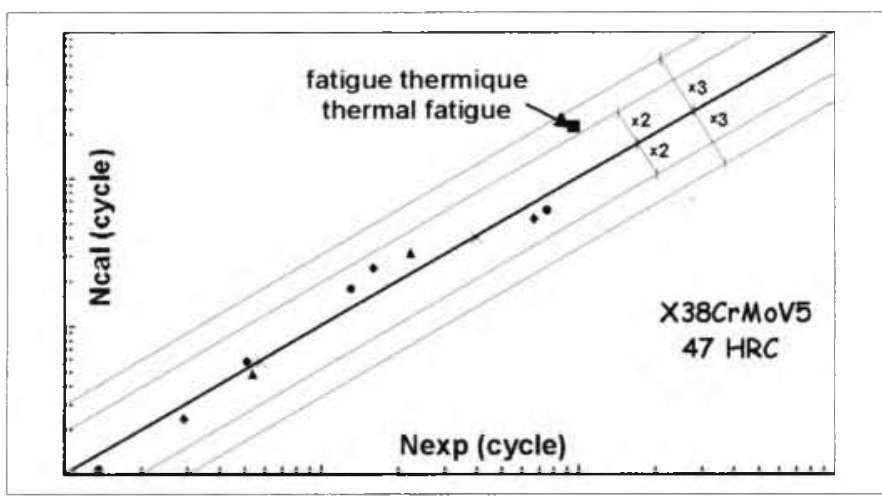

Fig. 8 - Comparison between calculated and experimental thermomechanical fatigue life.

Fig. 8 - Comparaison entre la durée de vie calculée et expérimentale en fatigue thermomécanique.

were calculated. As the model is uniaxial, only TSSts along $\mathrm{Z}$-axes were considered. From the thermomechanical analyses, "temperature-time" and "mechanical-temperature" cycles were extracted for some surface elements. Then, $T_{\max }$ and mechanical strain amplitudes $\left(\Delta \varepsilon_{m}\right)$ of each element were determined and used in a straightforward calculation software, to predict the fatigue life by equation (1) [13].

In TF specimens, themoelastoplastic analysis was carried-out, using ABAQUS $[2,16]$. Figure 8 shows the experimental and the predicted life of TMF as well as thermal fatigue specimens. Taking into account the limited conditions examined, and considering different approximations made, a good estimation of TMF life is achieved (factor 2 to 3 ).

A very few information was available on the actual thermal cycle of the tool, since no direct temperature measurements were performed. A new version of Forge $2^{\mathrm{TM}}$, permitting to run automatically several and successive forging operation simulations was used. The forging simulation was stopped after 25 cycles. The tool was considered to behave as thermoelastic. TSSts of different elements (points $A$ to $G$ in Figure 9) were then extracted from results files. These points correspond to some damaged regions observed on the tool (shown by arrows in this figure). The predicted TMF life of each point, $\mathrm{Ncal}$, is normalised by the smallest estimated TMF life (point A), taken as the "reference life", Nref. The prediction of the critical zones

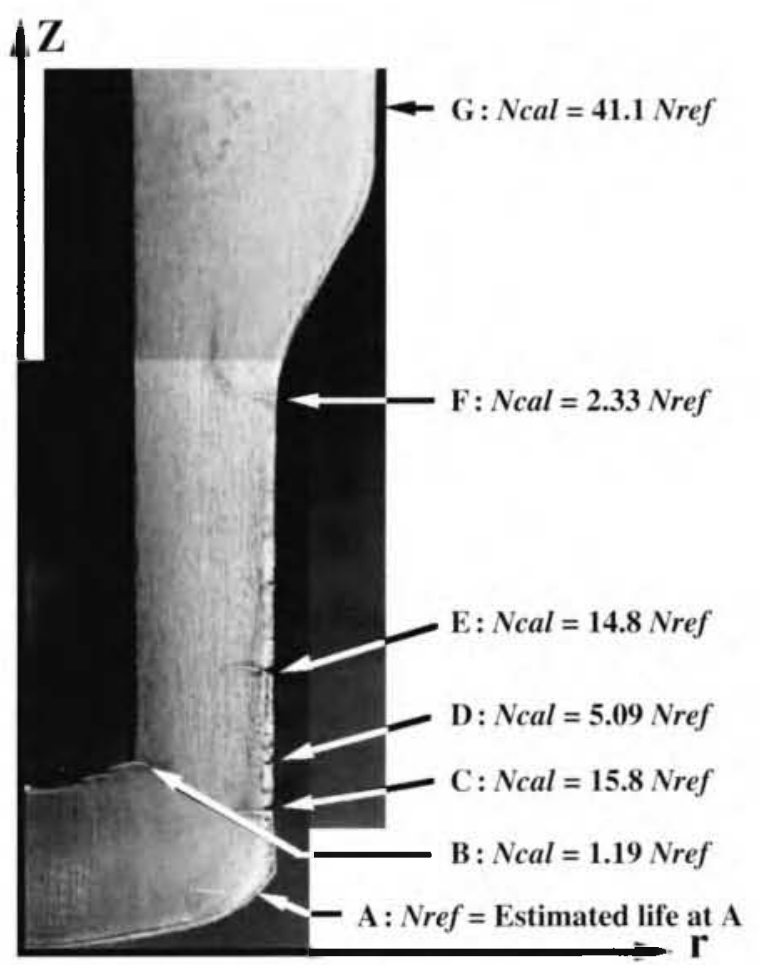

Fig. 9 - Predicted critical zones of an industrial hot work tool damaged by thermomechanical fatigue cracking.

Fig. 9 - Prédiction des zones critiques d'un outil industriel endommagé par fissuration en fatigue thermomécaniques.

is in good agreement with industrial observations and metallographic examinations performed at our laboratory.

The surface of tool at point $A$ is drastically damaged by wear-TMF interactions. Therefore, TMF cracks are not as visible as point $\mathrm{B}$ for example, where a very comparable TMF life was predicted. This is a very clear example of coupled sollicitations and complex damage mechanisms, frequently observed in hot work tools.

As mentioned earlier, TMF life corresponds to the number of cycles to form a macrocrack of about $0.5 \mathrm{~mm}$ depth. This is an engineering definition of the fatigue crack initiation life. Therefore, one can consider the model as "a fatigue crack initiation life prediction" approach.

\section{Summary}

A thermomechanical fatigue experiment using tubular specimens is developed. Two tempered martensitic steels, X38CrMoV5 (AISI $\mathrm{H} 11$ ) and 55NiCrMoV8 are assessed under out-of-phase thermomechanical cycles $\left(\varepsilon_{m \max }\right.$ at $T_{\min }$ and $\varepsilon_{m \text { min }}$ at $T_{\text {max }}$ ).

Softening is observed in both steels. Mean tensile stresses are developed in each steel. Detailed SEM observations reveal that cracks initiate under cyclic TMF-oxidation interactions. Based on TMF life curves, a phenomenological uniaxial model is proposed to predict the fatigue life of the hot work tool steels under non-isothermal fatigue sollicitations (i.e. thermal fatigue and thermomechanical fatigue). The model could predict some laboratory thermal fatigue life results within a factor two to three. The capability of the model to predict the critical regions of an industrial hot work tool, damaged by TMF cracking, is shown.

Acknowledgements : Authors gratefully acknowledge the French Research Action-II on Forging for its support. Technical assistance of Serge Tovar is acknowledged. Brice MIQUEL is kindly thanked for performing thermal fatigue experiences.

\section{REFERENCES}

[1] F. RÉZAI-ARIA, "Sollicitations thermo-mécaniques des outillages de forge à chaud", Journée du Cercle d'Études des Métaux "Voies de progrès dans l'industrie de la forge", St. Étienne, France, 25 mars 1999.
[2] S. Jean, B. Miquel, S. Leroux and F. Rézal-Aria, "An investigation on heat checking of hot work tool steels", Proceedings of $5^{\text {th }}$ international conference on tooling, Leoben, Austria, September $29^{\text {th }}$ to October $1^{\text {st }}, 1999$, pp. 185-194. 
[3] E. FELDER, "Modes d'usure et d'endommagement des cylindres de laminage à chaud. Caractéristiques thermomécaniques des calamines", Revue de métallurgie, 1984, pp. 931-942.

[4] M. LÉveque, "Principaux modes de dégradations des outillages à chaud pouvant conduire à la rupture", Traitement thermique, $n^{\circ} 231,1989$, pp. 47-52.

[5] C. Bournicon and J. P. Peyre, "Comportement en service d'outillage de forge avec revêtement dur". Traitement thermique, $n^{\circ} 231,1989$, pp. 53-56.

[6] D. Rousseau, J. P. Riegert, L. Séraphin and R. Tricot, "Fatigue thermique des aciers à outils pour travail à chaud", Revue de métallurgie, December 1975, pp. 875-889.

[7] Ch. Levaillant, "Enjeux et methodes en vue d'une approche globale de l'optimisation des outillages en acier", Bulletin du Cercle d'Études des Métaux, 37 Journées du Cercle d'Études des Métaux Colloque sur "Les Aciers pour Moules et Outils", 27-28 mai 1998, École des Mines d'Albi-Carmaux, 1998, pp. 1.2-1.9.

[8] D. Delagnes, F. Rézai-Aria, C. Levaillant et A. Grellier, "Comportement et durée de vie en fatigue isotherme de l'acier Z38CDV5", Matériaux et Techniques N ${ }^{\circ}$ 1-2 1999, pp. 39-50.

[9] F. Meyer-Olbersleben, D. Goldschmidt and F. RÉZAi-Aria, "Investigation of the thermal fatigue behaviour of single-crystal nickel-based superalloys SRR99 and CMSX-4", Superalloys 92, The Seventh International Symposium on Superalloys, Seven
Springs Mountain Resort, Champion, Pennsylvania, USA, Edited by S. D. Antolovich et al. 20-24 September 1992, pp. 785-794.

[10] A. Oudin and F. RÉZAI-ARIA, "Thermo-mechanical fatigue of a tempered martensitic $5 \%$ chromium steel", Proceedings of $5^{\text {th }}$ international conference on tooling, Leoben. Austria, September $29^{\text {th }}$ to October $1^{\text {st }}$, 1999, pp. 769-777.

[11] C. C. Engler-Pinto, Jr. and F. RéZAi-ARIa, "Thermo-mechanical fatigue investigation of single crystal nickel base superalloy SRR99", Thermo-mechanical fatigue behavior of materials, third volume, ASTM STP 1371, 2000, pp. 150-164.

[12] S. Broucaret, G. Dour, A. Oudin, A. Michrafy and F. RézalARIA, "Rôle du poteyage et de la température initiale du moule sur les sollicitations thermo-mécaniques des moules de fonderie" Matériaux et Techniques, ${ }^{\circ}$ hors série, déc. 2000, (présent recueil), pp. 45-50.

[13] A. Oudin and F. RÉZAl-ARIA, unpublished results, École des Mines d'Albi-Carmaux, 2000.

[14] J. L. MALPERTU and L. RÉMY, "Influence of test parameters on the thermal-mechanical fatigue behavior of a superalloy", Metallurgical Transactions A, Vol. 21A, 1990, pp. 389-399.

[15] B. Miquel and F. RÉZAi-ARIA, unpublished results, École des Mines d'Albi-Carmaux, 2000.

[16] Hibbit, KarLsSON \& SORENSEN Inc., ABAQUS Users manual, Version 4.9, Providence, 1991. 